\title{
Descriptive Study to Find out Antibiotic Susceptibility Pattern of the Clinical Isolates of Neonatal Septicemia
}

\author{
Deepti R. Angadi ${ }^{1 *}$, Latha Goravalingappa ${ }^{1}$ and Sreedevi Hanumantha ${ }^{2}$ \\ ${ }^{1}$ Department of Microbiology, PES Institute of Medical Sciences, Kuppam, \\ Chittoor, AP, India \\ ${ }^{2}$ GITAM Institute of Medical Sciences, Visakhapatnam, Andhra Pradesh, India \\ *Corresponding author
}

\begin{abstract}
A B S T R A C T
Keywords

Antibiotic

Susceptibility, Clinical

Isolates, Neonatal

Septicemia

Article Info

Accepted:

14 December 2017

Available Online:

10 January 2018

The most common causes of death in neonatal period are infections (32\%) including septicemia, meningitis, pneumonia, diarrhea and neonatal tetanus. It has also been documented that birth asphyxia contributes for $29 \%$ of deaths in neonatal period. Patients presented to department of pediatrics (NICU), were examined clinically by pediatricians and 122 cases of neonatal septicemia were identified on the basis of the signs and symptoms and were included for the study. This is followed by collection of blood for culture after obtaining informed expressed written consent.GPCs were predominantly susceptible to vancomycin and clindamycin whereas GNBs were predominantly susceptible to imipenem, eftazidime/clavulanic acid and chloramphenicol.
\end{abstract}

\section{Introduction}

Reported incidence of neonatal deaths is of about 5 million in a year according to the estimation of World Health Organization (WHO), (Rasul et al., 2007) among these 5 million deaths, it is observed that about $98 \%$ are occurring in developing countries within first week of life. Moreover, death rate widely varies in the developing countries between 1168/1000 live births in Asia, Africa and Latin America. It is assumed that neonatal mortality in the developing countries is under reported by at least $20 \%$. The most common causes of death in neonatal period are infections (32\%) including septicemia, meningitis, pneumonia, diarrhea and neonatal tetanus. It has also been documented that birth asphyxia contributes for $29 \%$ of deaths in neonatal period. (Bang et al., 2001)

Fetus is protected from the microbial flora of the mother by chorioamniotic membrane, the placenta and presence of anti-bacterial in amniotic fluid. Bacterial colonization of the neonate takes place after rupture of the maternal membranes. If the rupturing of the membranes lasts longer than 24hours, vaginal bacteria may ascend and in some cases produce inflammation of the fetal membranes, 
umbilical cord and placenta (Wientzen and McCracken, 1977). Neonates have relatively immature immune defense mechanisms. (Frank, 1979) But passively transferred specific IgG antibody from the mother in adequate concentration provides neonate protection against infection. The average concentration of $\operatorname{IgG}$ in a preterm infant is $400 \mathrm{mg} / \mathrm{dl}$ and in term infant it is $1000 \mathrm{mg} / \mathrm{dl}$. Since IgM and IgA antibodies are not transplacentally transferred from the mother, the foetus is able to synthesize pathogen specific antibodies, for instance, $\operatorname{IgM}$ and $\operatorname{IgA}$ antibodies in response to intrauterine infection but the production is inadequate. This gives us the reason for increased susceptibility of new born to infections. Furthermore, lack of transfer of complement also contributes for enhanced susceptibility of the new born to infections with GNBs. Newborn once infected, there is rapid multiplication and spread of infection to different organs through blood stream producing various systemic manifestations.

Leucopenia generally is observed in neonates. Production of $\mathrm{T}$ cells and cytokine production by macrophages are also seen in decreased amounts. Macrophage and natural killer cell functions are decreased leading to impaired phagocytosis and delay in response to infection

The treatment includes supportive therapy, antibiotic therapy and adjunctive therapy. Neonatal septicaemia is a life threatening emergency and accurate treatment with antibiotics is essential for a favourable outcome. Neonate with septicaemia needs to be given basic supportive care which includes providing of thermo neutral environment, oxygen supplementation along with ventilator support when required, regular monitoring of patient to keep in check of hypo glycaemia and hyper glycaemia. However, maintenance of blood pressure and normal tissue perfusion is done with colloides and ionotropes. In case of anaemia and bleeding diathesis, correction can be done by utilizing packed cells and fresh frozen plasma (Wientzen and McCracken, 1977)

Prior to the antibiotic era, the mortality attributed to septicaemia was $90 \%$ but it declined to $24-58 \%$ after antibiotic came into use. (Gupta et al., 1989) The empiric antimicrobial approach for neonatal sepsis has changed in many centres. In a study conducted by Mustafa and Ahmed it was observed that GPCs were susceptible to amikacin, cephalosporins and ciprofloxacin with higher susceptibility to linezolid and vancomycin. However, they were recorded more resistant to ampicillin and gentamicin. But higher resistance was documented for GNBs to commonly used antibiotics. (Agnihotri et al., 2004) in their retrospective study documented S.aureus including GNBs as resistant to amoxicillin, most of the strains of S.aureus being more sensitive to netilmicin. The authors (Agnihotri et al., 2004) concluded aminoglycosides, $\quad 3^{\text {rd }} \quad$ generation cephalosporins and quinolones as the most suitable drugs for the treatment of neonatal septicaemia. Appropriate antibiotic usage has been found effective in reducing resistance in few clinical settings. Hand washing has consistently shown reduction in incidence of nosocomial neonatal sepsis.

\section{Materials and Methods}

\section{Inclusion criteria}

Clinically suspected cases of neonatal septicaemia.

\section{Exclusion criteria}

Neonates clinically suspected of septicaemia but had received antibiotics were excluded from the study. 
Patients presented to department of pediatrics (NICU), were examined clinically by pediatricians and 122 cases of neonatal septicaemia were identified on the basis of the signs and symptoms and were included for the study. This is followed by collection of blood for culture after obtaining informed expressed written consent.

\section{Antibiotic susceptibility testing}

The clinical isolates obtained were subjected to antibiotic susceptibility testing by disc diffusion technique to determine the susceptibility pattern following the standard procedure. Briefly, bacterial inoculum for antibiotic susceptibility testing was prepared from 4-5 well-isolated colonies in nutrient broth medium. The broth culture was incubated at $37^{\circ} \mathrm{C}$. Suspension of the growing bacterium in broth medium with a turbidity equivalent to that of $0.5 \mathrm{McFarland}$ standard was cultured using a sterile swab over Mueller-Hinton agar by evenly spreading in three directions over the entire surface of the medium so as to obtain uniform growth.

Appropriate antibiotic discs (HIMEDIA, Mumbai, India) were applied maintaining a distance of $24 \mathrm{~mm}$ between 2 adjacent discs and the plates were incubated at $37^{\circ} \mathrm{C}$ after placing these discs. Simultaneously the test was carried out with standard bacterial strains of S.aureus ATCC 29213, E.coli ATCC 25922 and P.aeruginosa ATCC 27853. Clinical isolates indicating GPCs were tested for antibiotics such as amikacin, ampicillin, cefazolin, cefotaxime, ceftazidime, ceftazidime/clavulanic acid (when found resistance to ceftazidime), cefuroxime, ciprofloxacin, clindamycin, chloramphenicol, cotrimoxazole, erythromycin, gentamicin, netilmicin, penicillin $\mathrm{G}$, teicoplanin by disc diffusion technique mentioned above. While in vitro determination of vancomycin efficacy against GPCs (Except for Streptococcus species and Pneumococci that were tested by disc diffusion technique) was based on the minimal inhibitory concentration (MIC) values and performed by E-test method at Manipal hospital, Bengaluru and results were interpreted as per CLSI guidelines.

Staphylococcal strains were subjected to methicillin sensitivity testing by cefoxitin $30 \mu \mathrm{g}$ discs. GNBs were tested for antibiotic like amikacin, ampicillin, cefazolin, cefixime, cefotaxime, ceftazidime, ceftazidime/clavulanic acid (when found resistance to ceftazidime), cefuroxime, ciprofloxacin, chloramphenicol, cotrimoxazole, erythromycin, gentamicin, imipenem, netilmicin, ofloxacin. After 16-18 hours of incubation, the plates were examined and the diameter of the zone of complete inhibition around the discs was measured by a ruler. The diameter of zone of inhibition for individual antimicrobial agent was considered to state as sensitive or resistant by referring to an interpretative chart for the Kirby-Bauer method as per the recommendation of the CLSI. The antibiotic discs for the study were purchased from HIMEDIA, Mumbai, India.

Information regarding demographic characteristics like age and sex of patients, clinical manifestations including the risk factors, physical examination findings, microbiological data of the clinical isolate and other relevant laboratory parameters were all entered in the proforma and analyzed.

\section{Results and Discussion}

As depicted in tables 1 and 2, among 47 clinical isolates tested for antibiotic sensitivity, the pattern observed was - GPCs were predominantly susceptible to vancomycin and clindamycin whereas GNBs were predominantly susceptible to imipenem, ceftazidime/clavulanic acid and chloramphenicol. 
Table.1 Spectrum of antibiotic sensitivity pattern of 26 clinical isolates of GPCs

\begin{tabular}{|l|l|l|l|l|l|}
\hline Antibiotic & $\begin{array}{l}\text { No.(\%) of } \\
\text { MRSA strains } \\
\text { sensitive to } \\
\text { [out of 6 isolates } \\
\text { tested] }\end{array}$ & $\begin{array}{l}\text { No.(\%) of S. } \\
\text { aureus isolates } \\
\text { sensitive to } \\
\text { [out of 8 } \\
\text { isolates tested] }\end{array}$ & $\begin{array}{l}\text { No.(\%) of } \\
\text { CONS isolates } \\
\text { sensitive to } \\
\text { [out of } 9 \\
\text { isolates tested] }\end{array}$ & $\begin{array}{l}\text { No.(\%) of } \\
\text { Streptococusis } \\
\text { olates sensitive } \\
\text { to } \\
\text { [out of 2 } \\
\text { isolates tested] }\end{array}$ & $\begin{array}{l}\text { No.(\%)of } \\
\text { Pneumococcus } \\
\text { isolate sensitive to } \\
\text { [out of } 1 \text { isolate } \\
\text { tested] }\end{array}$ \\
\hline Ampicillin & $3(50)$ & $1(12.50)$ & $4(44.44)$ & $00(00)$ & $00(00)$ \\
\hline Cefazolin & $2(33.33)$ & $4(50)$ & $2(22.22)$ & $1(50)$ & $00(00)$ \\
\hline Cefotaxime & $2(33.33)$ & $1(12.50)$ & $2(22.22)$ & $00(00)$ & $00(00)$ \\
\hline Ceftazidime & $2(33.33)$ & $1(12.50)$ & $1(11.11)$ & $00(00)$ & $00(00)$ \\
\hline Cefuroxime & $4(66.66)$ & $5(62.50)$ & $2(22.22)$ & $00(00)$ & $00(00)$ \\
\hline Ciprofloxacin & $3(50)$ & $5(62.50)$ & $2(22.22)$ & $1(50)$ & $1(100)$ \\
\hline Clindamycin & $6(100)$ & $8(100)$ & $2(22.22)$ & $2(100)$ & $00(00)$ \\
\hline Chloramphenicol & $5(83.33)$ & $8(100)$ & $2(22.22)$ & $1(50)$ & $1(100)$ \\
\hline Cotrimoxazole & $3(50)$ & $6(75)$ & $2(22.22)$ & $1(50)$ & $1(100)$ \\
\hline Erythromycin & $00(00)$ & $1(12.50)$ & $2(22.22)$ & $00(00)$ & $00(00)$ \\
\hline Gentamicin & $2(33.33)$ & $5(62.50)$ & $2(22.22)$ & $00(00)$ & $00(00)$ \\
\hline Netilmicin & $5(83.33)$ & $6(75)$ & $2(22.22)$ & $1(50)$ & $1(100)$ \\
\hline Ofloxacin & $5(83.33)$ & $3(37.50)$ & $2(22.22)$ & $1(50)$ & $1(100)$ \\
\hline Penicillin G & $00(00)$ & $1(12.50)$ & $3(33.33)$ & $00(00)$ & $00(00)$ \\
\hline Teicoplanin & $00(00)$ & $1(12.50)$ & $3(33.33)$ & $00(00)$ & $00(00)$ \\
\hline Vancomycin & $6(100)$ & $8(100)$ & $9(100)$ & $2(100)$ & $1(100)$ \\
\hline
\end{tabular}

Table.2 Spectrum of antibiotic sensitivity pattern of 21 clinical isolates of GNBs

\begin{tabular}{|l|}
\hline Antibiotic \\
\\
\hline Ampicillin \\
\hline Cefozolin \\
\hline Cefexime \\
\hline Cefotaxime \\
\hline Ceftazidime \\
\hline Ceftazidime/Clavulanic acid \\
\hline Chloramphenicol \\
\hline Cefuroxime \\
\hline Ciprofloxacin \\
\hline Cotrimaxazole \\
\hline Erythromycin \\
\hline Gentamicin \\
\hline Imipenem \\
\hline Netilmicin \\
\hline Ofloxacin \\
\hline
\end{tabular}

\begin{tabular}{|l|l|}
\hline $\begin{array}{l}\text { No.(\%) of } \boldsymbol{K} . \\
\text { aerogenes } \\
\text { isolates } \\
\text { sensitive to } \\
\text { [out of } 14 \\
\text { isolates } \\
\text { tested] }\end{array}$ & $\begin{array}{l}\text { No.(\%) of } \\
\text { P.aeruginosa } \\
\text { isolate } \\
\text { sensitive to } \\
\text { [out of } 1 \\
\text { isolate tested] }\end{array}$ \\
\hline $00(00)$ & $00(00)$ \\
\hline $00(00)$ & $00(00)$ \\
\hline $00(00)$ & $00(00)$ \\
\hline $2(14.28)$ & $00(00)$ \\
\hline $00(00)$ & $00(00)$ \\
\hline $10(71.42)$ & $1(100)$ \\
\hline $11(78.37)$ & $1(100)$ \\
\hline $00(00)$ & $00(00)$ \\
\hline $8(57.14)$ & $00(00)$ \\
\hline $10(71.42)$ & $00(00)$ \\
\hline $00(00)$ & $00(00)$ \\
\hline $5(35.71)$ & $00(00)$ \\
\hline $13(98.85)$ & $00(00)$ \\
\hline $2(14.28)$ & $00(00)$ \\
\hline $3(21.42)$ & $00(00)$ \\
\hline
\end{tabular}

\begin{tabular}{|l|l|l|}
\hline $\begin{array}{l}\text { No. }(\%) C . \\
\text { freundii } \\
\text { isolate } \\
\text { sensitive to } \\
\text { [out of } 1 \\
\text { isolate } \\
\text { tested] }\end{array}$ & $\begin{array}{l}\text { No.(\%) of } \\
\text { E. coli } \\
\text { isolate } \\
\text { sensitive } \\
\text { to [out of } \\
\text { isolate } \\
\text { tested] }\end{array}$ & $\begin{array}{l}\text { No.(\%)of } \\
\text { Acinetobacter } \\
\text { isolates } \\
\text { sensitive to } \\
\text { [out of 4 } \\
\text { isolates tested] }\end{array}$ \\
\hline $00(00)$ & $00(00)$ & $00(00)$ \\
\hline $00(00)$ & $00(00)$ & $00(00)$ \\
\hline $00(00)$ & $00(00)$ & $00(00)$ \\
\hline $00(00)$ & $00(00)$ & $00(00)$ \\
\hline $00(00)$ & $00(00)$ & $00(00)$ \\
\hline $1(100)$ & $1(100)$ & $4(36.36)$ \\
\hline $1(100)$ & $1(100)$ & $3(27.27)$ \\
\hline $00(00)$ & $00(00)$ & $2(18.18)$ \\
\hline $00(00)$ & $00(00)$ & $00(00)$ \\
\hline $1(100)$ & $00(00)$ & $3(27.27)$ \\
\hline $00(00)$ & $00(00)$ & $00(00)$ \\
\hline $00(00)$ & $00(00)$ & $00(00)$ \\
\hline $1(100)$ & $1(100)$ & $2(18.18)$ \\
\hline $00(00)$ & $00(00)$ & $00(00)$ \\
\hline $1(100)$ & $00(00)$ & $1(9.09)$ \\
\hline & & \\
\hline
\end{tabular}


Table.3 Antibiotic susceptibility pattern of GPCs in different studies

\begin{tabular}{|c|c|c|c|}
\hline $\begin{array}{l}\text { Authors and } \\
\text { reference }\end{array}$ & Region & $\begin{array}{l}\text { Most sensitive } \\
\text { antibiotic/s against } \\
\text { Gram positive cocci }\end{array}$ & $\begin{array}{l}\text { Antibiotic/s to which } \\
\text { most Gram positive } \\
\text { cocci were resistant }\end{array}$ \\
\hline Tallur et al., (2000) & Hubballi,, Karnataka & $\begin{array}{l}\text { Gentamicin } \\
\text { Amikacin } \\
\text { Tobramycin }\end{array}$ & Ampicillin \\
\hline $\begin{array}{l}\text { Kaistha et al., } \\
(2009)\end{array}$ & Chandigarh & Vancomycin (100\%) & $\begin{array}{l}\text { Gentamicin }(50 \%) \\
\text { Erythromycin }(46.5 \%)\end{array}$ \\
\hline $\begin{array}{l}\text { Aletayeb et al., } \\
(2011)\end{array}$ & Ahvaz, Iran & Vancomycin (100\%) & $\begin{array}{l}\text { Ampicillin }(100 \%) \\
\text { Penicillin }(100 \%)\end{array}$ \\
\hline Present study & Belagavi, Karnataka & $\begin{array}{l}\text { Vancomycin }(100 \%) \\
\text { Clindamycin } \\
(69.23 \%)\end{array}$ & $\begin{array}{l}\text { Erythromycin }(88.46 \%) \\
\text { Teicoplanin }(84.61 \%) \\
\text { PenicillinG }(84.61 \%)\end{array}$ \\
\hline
\end{tabular}

Table.4 Antibiotic susceptibility pattern of GNBs in different studies

\begin{tabular}{|c|c|c|c|}
\hline $\begin{array}{l}\text { Authors and } \\
\text { reference }\end{array}$ & Region & $\begin{array}{l}\text { Most sensitive antibiotic/s } \\
\text { against Gram negative } \\
\text { bacilli }\end{array}$ & $\begin{array}{l}\text { Antibiotic/s to which } \\
\text { most Gram negative } \\
\text { bacilli were resistant }\end{array}$ \\
\hline $\begin{array}{l}\text { Tallur et al., } \\
(2000)\end{array}$ & Hubballi, Karnataka & $\begin{array}{l}\text { Gentamicin } \\
\text { Amikacin } \\
\text { Tobramycin }\end{array}$ & Ampicillin \\
\hline $\begin{array}{l}\text { Kaistha et al., } \\
(2009)\end{array}$ & Chandigarh & $\begin{array}{l}\text { Amikacin } \\
\text { Imipenem }\end{array}$ & $\begin{array}{l}\text { Amoxycillin }(62 \%) \\
\text { Ampicillin }(83 \%)\end{array}$ \\
\hline $\begin{array}{l}\text { Aletayeb et al., } \\
(2011)\end{array}$ & Ahvaz, Iran & Imipenem (100\%) & $\begin{array}{l}\text { Ampicillin }(100 \%) \\
\text { Gentamicin }(100 \%)\end{array}$ \\
\hline Present study & $\begin{array}{l}\text { Belagavi, } \\
\text { Karnataka }\end{array}$ & $\begin{array}{l}\text { Imipenem }(80.95 \%) \\
\text { Ceftazidime/ } \\
\text { Clavulanicacid }(80.95 \%) \\
\text { Chloramphenicol }(80.95 \%)\end{array}$ & $\begin{array}{l}\text { Ampicillin }(100 \%) \\
\text { Cefazolin }(100 \%) \\
\text { Erythromycin }(100 \%)\end{array}$ \\
\hline
\end{tabular}

In this study, all of the GPCs were found sensitive to vancomycin clindamycin susceptibility being observed in $69.23 \%$ isolates only while resistance was noted most commonly for erythromycin $(88.46 \%)$ followed by teicoplanin $(84.61 \%)$ and penicillin $G$ (84.61\%). (Aletayeb et al., 2011) have documented all of their GPCs showing $100 \%$ resistance to commonly used antibiotics such as ampicillin and penicillin. GPCs were detected most sensitive to gentamicin, amikacin and tobramycin in a study carried out by (Tallur et al., 2000) while ampicillin was reported as the most resistant antibiotic. (Kaistha et al., 2009) found all their GPCs sensitive to vancomycin $(100 \%)$, whereas gentamicin $(50 \%)$ and erythromycin $(46.5 \%)$ as most resistant antibiotics among all GPCs. (Aletayeb et al., 2011) also documented all of their GPC isolates sensitive to vancomycin (100\%) in their study. The reasons for $100 \%$ sensitivity of GPCs for vancomycin could be due to its restricted use to 
MRSA infections only and also because it was reported resistant by disc diffusion technique which was applied earlier to test vancomycin sensitivity which had further minimized its use in clinical situations by the practicing clinicians. Additionally, it is also one of the rarely used drug like clindamycin and amikacin, hence, these drugs have not developed significant resistance mechanisms unlike any other widely used antibiotics Ampicillin, penicillin and erythromycin have developed high level resistance as they are most commonly and widely used drugs. None of our Gram positive coccal isolates demonstrated $100 \%$ sensitivity to any of the antibiotics except vancomycin. Similarly, none of our Gram positive coccal isolates were noted $100 \%$ resistance to any of the antibiotics tested - the findings that are noteworthy (Tables 3 and 4).

It was observed that in the present study most of the GNBs were sensitive to imipenem $(80.95 \%)$, ceftazidime/clavulanic acid $(80.95 \%)$ and chloramphenicol $(80.95 \%)$. It is worth knowing and alarming that all our GNBs demonstrated $100 \%$ resistance to ampicillin, cefazolin, and erythromycin. (Aletayeb et al., 2011) also reported the $100 \%$ resistance of ampicillin and gentamicin to all GNB isolates with $100 \%$ sensitive to imipenem. (Tallur et al., 2000) found gentamicin, amikacin, tobramycin as most effective antibiotics and ampicillin as most resistant antibiotic against GNBs. (Kaistha et al., 2009) recorded amikacin and imipenem as most sensitive and effective antibiotics against GNBs whereas amoxicillin (62\%) and ampicillin $(83 \%)$ as least clinically useful antibiotics. Wide variation in antimicrobial sensitivity patterns is noted from region to region and from time to time in the medical literature, which could be to the rise in resistant strains as a result of irrational use of antibiotics in a given defined region.
Most effective antibacterial agents found were vancomycin and clindamycin against GPCs, while imipenem and ceftazidime/clavulanic acid and chloramphenicol against GNBs.

\section{References}

Agnihotri N. Kaisath N. Gupta V. Antimicrobial susceptibility of isolates from neonatal septicaemia. Jpn J Infect Dis. 2004; 57: 273-75.

Aletayeb SMH, Khosravi AD, Dehdashtian M, Kompani F, Mortazavi SM, Aramesh MR. Identification of bacterial agents and antimicrobial susceptibility of neonatal sepsis: A 54-month study in a tertiary hospital. Afr J Microbiol Res. 2011; 5: 528531.

Bang AJ, Bang RA, Baitule S, Deshmukh M, Reddy MH. Burden of morbidities and unmet need for health care in rural Indian neonate". Indian Pediatr. 2001; 38: 952-65.

Frank MM. The complement system in host defence and inflammation. Rev Infect Dis. 1979; 1:483-501.

Gupta SK, Sharma U, Gupta ML, Sharma DK. Acridine orange stain a rapid method for diagnosis of neonatal septicaemia. Indian Pediatr. 1989; 26: 153-55.

Kaistha N, Mehta M, Singla N, Garg R, Chander J. Neonatal septicemia isolates and resistance patterns in a tertiary care hospital of North India. J Infect DevCtries. 2009; 4: 055-057.

Rasul CH, Hassan MA, Habibullah M. Neonatal sepsis and use of antibiotic in a tertiary care hospital Pak J Med Sci. 2007; 23: 78-81

Tallur SS, Kasturi AV, Nadgir SD, Krishna BV. Clinico-bacteriological study of neonatal septicemia in Hubli. Indian J Pediatr. 2000; 67: 169-174.

Wientzen RL and McCracken GH. Pathogenesis and management of neonatal sepsis and meningitis. Curr Probl Pediatr 1977; 8:1-61.

\section{How to cite this article:}

Deepti R. Angadi and Sreedevi Hanumantha. 2018. Descriptive Study to Find out Antibiotic Susceptibility Pattern of the Clinical Isolates of Neonatal Septicemia. Int.J.Curr.Microbiol.App.Sci. 7(01): 2034-2039. doi: https://doi.org/10.20546/ijcmas.2018.701.245 